\title{
Serine/Threonine-Protein Kinase PAK 1
}

National Cancer Institute

\section{Source}

National Cancer Institute. Serine/Threonine-Protein Kinase PAK 1. NCI Thesaurus. Code C42594.

Serine/threonine-protein kinase PAK 1 (545 aa, $\sim 61 \mathrm{kDa}$ ) is encoded by the human PAK1 gene. This protein is involved in both protein phosphorylation and signal transduction. 